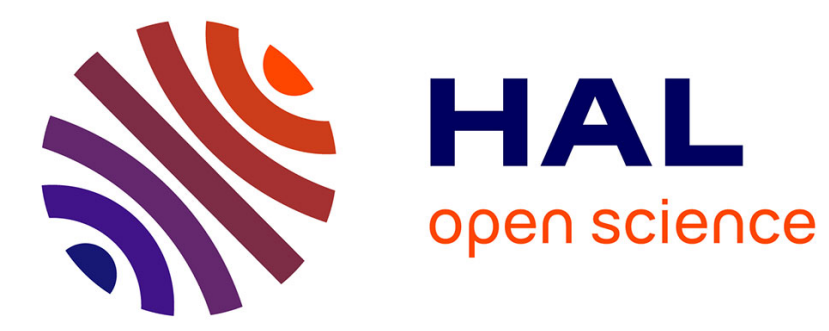

\title{
Caesium uptake by Callovian-Oxfordian clayrock under alkaline perturbation
}

\author{
Stéphane Gaboreau, Francis Claret, Catherine Crouzet, Eric Giffaut, \\ Christophe Tournassat
}

\section{- To cite this version:}

Stéphane Gaboreau, Francis Claret, Catherine Crouzet, Eric Giffaut, Christophe Tournassat. Caesium uptake by Callovian-Oxfordian clayrock under alkaline perturbation. International meeting "Clays in Natural and Engineered Barriers for Radioactive Waste Confinement", Oct 2012, Montpellier, France. hal-00705340

\section{HAL Id: hal-00705340 https://hal-brgm.archives-ouvertes.fr/hal-00705340}

Submitted on 7 Jun 2012

HAL is a multi-disciplinary open access archive for the deposit and dissemination of scientific research documents, whether they are published or not. The documents may come from teaching and research institutions in France or abroad, or from public or private research centers.
L'archive ouverte pluridisciplinaire HAL, est destinée au dépôt et à la diffusion de documents scientifiques de niveau recherche, publiés ou non, émanant des établissements d'enseignement et de recherche français ou étrangers, des laboratoires publics ou privés. 


\title{
Caesium uptake by Callovian-Oxfordian clayrock under alkaline perturbation
}

\author{
S. Gaboreau $^{1}$, F. Claret ${ }^{1}$, C. Crouzet ${ }^{1}$, E. Giffaut ${ }^{2}$, Ch. Tournassat $^{1}$ \\ 1. BRGM (French Geological Survey), 3, Avenue Claude Guillemin, 45060 Orleans Cedex, France \\ 2. ANDRA, 1-7 Rue Jean Monnet, 92298 Châtenay-Malabry, France
}

Caesium is one of the main radionuclides present in radioactive waste. ${ }^{135} \mathrm{Cs}$ has a very long half-life $\left(\sim 2.310^{6} \mathrm{yr}\right)$ and $\mathrm{Cs}$ is, therefore, one of the main safety relevant elements (Kissane, 2009). For these reasons, Cs is one of the most widely studied radionuclides in environmental sciences. Numerous works have been devoted to developing sorption models enabling the prediction of Cs sorption in clayrich media. These models consider the presence of different exchange sites at clay surfaces having various relative affinities for Cs and other cations present in solution (Bolt et al., 1963; Jackson, 1968; Sposito, 1980; Brouwer et al., 1983; Bradbury and Baeyens, 2000; Steefel et al., 2003; Wang et al., 2011). Illite has been identified as the main mineral responsible for the uptake of Cs due to the high affinity of its surfaces for Cs ions. Caesium sorption on illite surfaces can be successfully modelled by considering up to three different exchange sites denoted as frayed edge sites (FES), planar sites on the basal surfaces and type II sites whose morphological or structural origin is not well defined (Bradbury and Baeyens, 2000). Of these sites, frayed edge sites are responsible for the very high Cs affinity for illite surfaces at low Cs concentrations.

Concepts of a radioactive waste repository in deep clay formations take advantage of this Cs retention by the geological barrier. Nevertheless, although many studies have focused on the prediction of Cs sorption and mobility in this context (Poinssot et al., 1999; Bradbury and Baeyens, 2000; Van Loon et al., 2009), few have been dedicated to the study of Cs retention by the clay-rich media under perturbations due to the presence of the repository structure, the engineered barriers and the waste containers. According to the numerous data produced on alkaline perturbation (Gaucher and Blanc, 2006; Fernandez et al., 2009; Dauzeres et al., 2010; Gaboreau et al., 2011), the use of cement materials in the repository design is assumed to alter the confining properties of the clay buffer plug. Over a long time scale, the degradation of the clays could induce a diminution of their physical and chemical properties by the dissolution of the clay minerals at high $\mathrm{pH}$ and by the release of competitive cations for $\mathrm{Cs}$ retention such as $\mathrm{K}^{+}$, mainly originating from the cement material alkali-rich pore-water. The quantification and the modeling prediction of these effects are important issues in order to attribute a retention performance to the barrier as a function of pertinent markers of the disturbance (changes in mineral phase composition, concentration levels of competing ions).

The potential effect of a near-field alkaline perturbation is therefore explored in the present study. Batch experiments were conducted to measure the Cs sorption in alkaline perturbed conditions. These experiments aimed at mimicking the effect of an alkaline plume intrusion on COx with accompanying changes in $\mathrm{pH}$ and other solution parameters such as $\mathrm{K}$ concentration. The second system mimic an interface (clayrock/cement materials) during early reaction time and the last system was an assemblage of minerals representative of the concrete/clay interfaces during long reaction time. A predictive sorption model taken from the literature was applied to identify discrepancies between measured and predicted retention properties.

The experimental data, for Cs sorption on Callovian-Oxfordian argillaceous rock under short term (one day) alkaline perturbation, shows that $\mathrm{K}^{+}$competition for $\mathrm{Cs}^{+}$sorption on illite FES sites is the main factor affecting Cs retention capacities. This competitive effect related to the intrusion of hydrated cement pore water in the argillaceous rock is well predicted by the model of Bradbury and Baeyens (2000) without considering any corrections/adjustment in the original model. It is thus possible to make reliable prediction of Cs retention level as a function of $\mathrm{K}^{+}$intrusion in the rock. For instance, from coupled geochemistry/transport modeling $\mathrm{K}^{+}$diffusion in the rock after 10000 years should lead to a $\mathrm{K}^{+}$concentration up to $20 \mathrm{mmol} / \mathrm{L}$ ten centimeter after the interface (corresponding $\mathrm{Kd} \sim 90 \mathrm{~L} / \mathrm{kg}$ ) whereas this concentration increase should be limited to $3 \mathrm{mmol} / \mathrm{L}$ at $0.5 \mathrm{~m}$ of the interface (corresponding $\mathrm{Kd} \sim 160 \mathrm{~L} / \mathrm{kg}$ ). For one month experiments, an additional contribution to the overall Cs sorption is measured and can probably be attributed to sorption or co-precipitation on newly 
formed minerals, e.g. C-S-H phases (Figure 1). Experiments on a mineralogical assemblage representative of a Callovian-Oxfordian rock/concrete interface showed that this mineralogical assemblage has a similar efficiency for $\mathrm{Cs}$ uptake as the intact clay rock. The chosen mineral assemblage is representative of a highly perturbed material and corresponds to an interface composition modeled after thousand years of cement clay interaction (Marty et al. 2009). This result shows that clay barrier material transformation under long term alkaline perturbation can lead to similar barrier performance as for undisturbed barriers with regard to Cs retention.
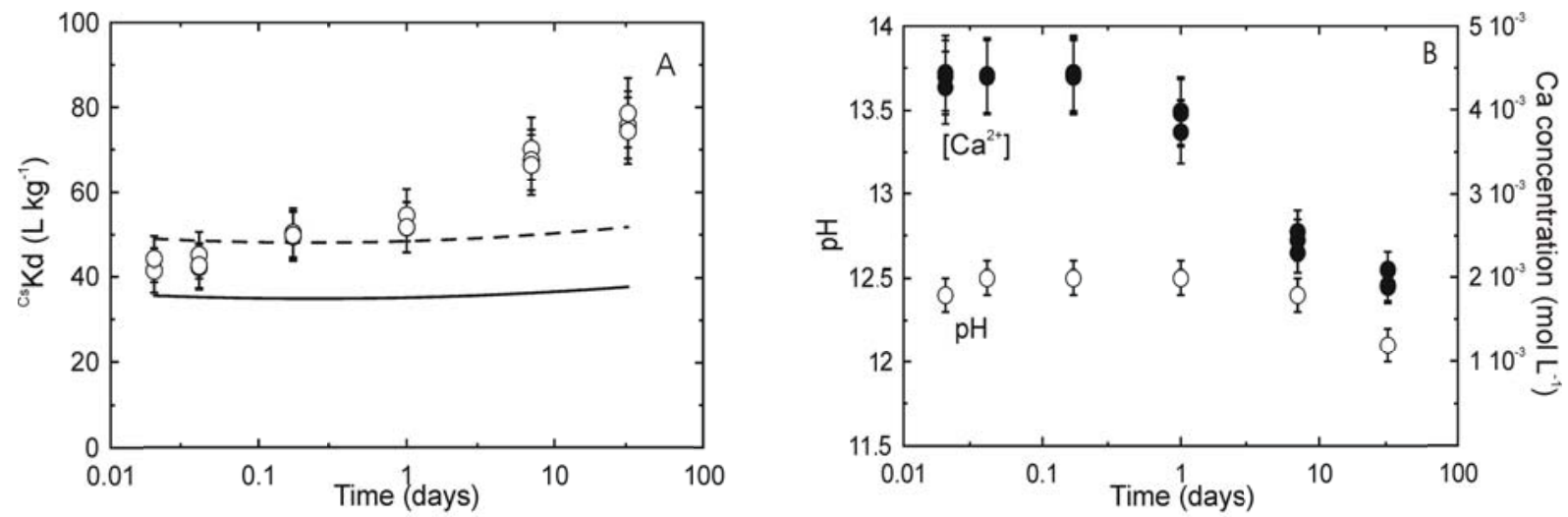

Figure 1. A. Cs sorption kinetics experiment on crushed COx clay rock in contact with COx and hydrated cement pore water mixed synthetic pore waters (o). The dashed and continuous lines correspond to a predictive model of the data. Two hypotheses were tested: (i) FES are borne only by illite crystallite (continuous line) or (ii) FES are borne both by illite crystallite and illite layers in IS R0 (dashed line). The Cs concentration added = $110^{-5} \mathrm{~mol} \mathrm{~L}^{-1}$. B. $\mathrm{pH}$ of the suspension $(\circ)$ and Ca concentration $(\bullet)$ as a function of time.

\section{References}

Bradbury, M.H., Baeyens, B., 2000. A generalised sorption model for the concentration dependent uptake of caesium by argillaceous rocks. J. Contam. Hydrol. 42, 141-163.

Bolt, G.H., Summer, M.E., Kamphorst, A., 1963. A study of the equilibrium between three categories of potassium in an illitic soil. Soil Sci. Soc. Am. Proc. 27, 294-299.

Brouwer, E., Baeyens, B., Maes, A., Cremers, A., 1983. Cesium and rubidium ion equilibria in illite clay. J. Phys. Chem. 87 , 1213-1219.

Dauzeres, A., Le Bescop, P., Sardini, P., Coumes, C.C.D., 2010. Physico-chemical investigation of clayey/cement-based materials interaction in the context of geological waste disposal: Experimental approach and results. Cement Concrete Res. 40, 1327-1340.

Fernandez, R., Mader, U.K., Rodriguez, M., de la Villa, R.V., Cuevas, J., 2009. Alteration of compacted bentonite by diffusion of highly alkaline solutions. Eur. J. Mineral. 21, 725-735.

Gaboreau, S., Pret, D., Tinseau, E., Claret, F., Pellegrini, D., Stammose, D., 2011. 15 years of in situ cement argillite interaction from Tournemire URL: Characterisation of the multi-scale spatial heterogeneities of pore space evolution. Appl. Geochem. 26, 2159-2171.

Gaucher, E.C., Blanc, P., 2006. Cement/clay interactions - A review: Experiments, natural analogues, and modeling. Waste Manage. 26, 776-788.

Jackson, M.L., 1968. Weathering of primary and secondary minerals in soils. International Society of Soil Science 4, 281-292 Kissane, M.P., 2009. A review of radionuclide behaviour in the primary system of a very-high-temperature reactor. Nucl. Engin. Design 239, 3076-3091.

Marty, N.C.M., Tournassat, C., Burnol, A., Giffaut, E., Gaucher, E.C., 2009. Influence of reaction kinetics and mesh refinement on the numerical modelling of concrete/clay interactions. J. Hydrol. 364, 58-72.

Poinssot, C., Baeyens, B., Bradbury, M.H., 1999. Experimental and modelling studies of caesium sorption on illite. Geochim. Cosmochim. Acta 63, 3217-3227.

Sposito, G., 1980. Derivation of the Freundlich Equation for Ion-Exchange Reactions in Soils. Soil Sci. Soc. Am. J. 44, $652-$ 654.

Steefel, C.I., Carroll, S., Zhao, P.H., Roberts, S., 2003. Cesium migration in Hanford sediment: a multisite cation exchange model based on laboratory transport experiments. J. Contam. Hydrol. 67, 219-246.

Van Loon, L.R., Baeyens, B., Bradbury, M.H., 2009. The sorption behaviour of caesium on Opalinus Clay: A comparison between intact and crushed material. Appl. Geochem. 24, 999-1004.

Wang, T.-H., Chen, C.-L., Ou, L.-Y., Wei, Y.-Y., Chang, F.-L., Teng, S.-P., 2011. Cs sorption to potential host rock of lowlevel radioactive waste repository in Taiwan: Experiments and numerical fitting study. J. Hazard. Mater. 192, 1079-1087. 